\title{
Spatial distribution of mercury in topsoil from five regions of China
}

\author{
Jian-bo Shi • Mei Meng • Jun-juan Shao • \\ Ke-gang Zhang • Qing-hua Zhang • Gui-bin Jiang
}

Received: 28 April 2012 / Accepted: 27 July 2012 /Published online: 11 August 2012

(C) Springer-Verlag 2012

\begin{abstract}
The concentrations and distributions of mercury $(\mathrm{Hg})$ in topsoil from four provinces and one municipality in China were investigated. A total of 1,254 samples were collected and analyzed. The average concentrations of $\mathrm{Hg}$ were $0.064 \mathrm{mg} \mathrm{kg}^{-1}$ for Liaoning Province, $0.100 \mathrm{mg} \mathrm{kg}^{-1}$ for Jiangsu Province, $0.110 \mathrm{mg} \mathrm{kg}^{-1}$ for Zhejiang Province, $0.154 \mathrm{mg} \mathrm{kg}^{-1}$ for Sichuan Province, and $0.098 \mathrm{mg} \mathrm{kg}^{-1}$ for Chongqing Municipality. Although differences were found among the ranges of $\mathrm{Hg}$ concentrations, the average values for each region were similar with other published data. The concentrations of $\mathrm{Hg}$ in topsoil varied largely upon the sampling locations. More than $80 \%$ of the soil samples from Liaoning Province, Jiangsu Province, Zhejiang Province, and Chongqing Municipality, were ranked Grade I by the China Environmental Quality Standard for Soils, which can be considered as not contaminated by $\mathrm{Hg}$. The concentrations of $\mathrm{Hg}$ in $0.3-$ $0.4 \%$ of soils collected from Jiangsu Province, Zhejiang Province and Chongqing Municipality exceeded the limitation for Grade III, indicating the contamination of $\mathrm{Hg}$ in these sites. The sources and potential risks of $\mathrm{Hg}$ in these sites should be brought to attention and further investigated.
\end{abstract}

Keywords Mercury $\cdot$ Soil $\cdot$ Spatial distribution $\cdot$ China

Responsible editor: Zhihong Xu

J.-b. Shi $\cdot$ M. Meng $\cdot$ J.-j. Shao $\cdot$ K.-g. Zhang $\cdot$ Q.-h. Zhang $\cdot$

G.-b. Jiang $(\bowtie)$

State Key Laboratory of Environmental Chemistry and

Ecotoxicology, Research Center for Eco-Environmental Sciences,

Chinese Academy of Sciences,

P.O. Box 2871, Beijing 100085, China

e-mail: gbjiang@rcees.ac.cn

\section{Introduction}

As a toxic and global pollutant, mercury $(\mathrm{Hg})$ has been of wide public health concern during the last century. Although there are some natural emissions of $\mathrm{Hg}$ from volcanoes, forest fires and evaporation from soil and water, anthropogenic emissions are considered the main sources for the global $\mathrm{Hg}$ contamination. Currently, there are more than 2,000 tonnes of $\mathrm{Hg}$ emitted every year by human activities, such as coal combustion, mining and smelting, and industrial usage of $\mathrm{Hg}$ in batteries, electric lighting, medical devices, and more (Pirrone et al. 2010; Streets et al. 2011).

China has a long history of mining and using of $\mathrm{Hg}$. With the rapid economic development in the past decades, the amount of $\mathrm{Hg}$ consumed and released also increased significantly (Feng 2005; Jiang et al. 2006). The total demand of Hg from different sectors exceeded 1,500 tonnes in 2007, about $40 \%$ increase compared with that in 2004 (Jian et al. 2009). Almost all the 11 categories and 59 sub-categories of emission sources defined by the UNEP Toolkit for Identification and Quantification of Mercury Release (UNEP 2010) are present in China. Although there is still a large uncertainty, the amount of $\mathrm{Hg}$ emitted from China was estimated in the range of 600 700 tonnes/year (Pacyna et al. 2006; Wu et al. 2006), accounting for about $30 \%$ of the global emission. However, the fate of these emitted $\mathrm{Hg}$ was little studied and is not clear until now.

Besides aquatic system, soil is another important sink and source of $\mathrm{Hg}$. As a natural element, $\mathrm{Hg}$ is widely present in soils at a certain level since the Earth was formed. Hg could also be introduced and accumulated in soil through various pathways, such as dry and wet deposition from atmosphere, release from waste products, and application of fertilizers and pesticides containing $\mathrm{Hg}$. As a result, the content of $\mathrm{Hg}$ in soil may increase with growing anthropogenic activities. On the other hand, $\mathrm{Hg}$ in soil could be evaporated to the atmosphere, 
leached by water, or accumulated in plant. Thus, soil becomes an important source of $\mathrm{Hg}$. Recent studies in Guizhou Province, southwestern China, have showed that rice is the major pathway for methylmercury $(\mathrm{MeHg})$ exposure to humans, in which $\mathrm{MeHg}$ is mainly accumulated from soil (Meng et al. 2010, 2011; Qiu et al. 2008; Zhang et al. 2010). Therefore, monitoring the concentrations of $\mathrm{Hg}$ in soil is important for understanding the geochemical cycle of $\mathrm{Hg}$ in the environment.

Investigations from different countries showed that the $\mathrm{Hg}$ concentrations is in the range of $0.01-1 \mathrm{mg} \mathrm{kg}^{-1}$ in soils without known nearby contamination sources and $0.1-$ $10 \mathrm{mg} \mathrm{kg}^{-1}$ in urban and industrial soils, while very high values were found in soils close to $\mathrm{Hg}$ mines (Tipping et al. 2011). A survey conducted by the China National Environmental Monitoring Center in 1990 showed that the national average concentrations of $\mathrm{Hg}$ in topsoil were $0.065 \mathrm{mg} \mathrm{kg}^{-1}$ (Wei et al. 1991). However, there have been little available update data since the survey. Our recent studies in Pearl River Delta, one of the most industrialized and urbanized region in China, has shown that the concentrations of $\mathrm{Hg}$ in the sediments increased with the economic development in the last three decades (Shi et al. 2007, 2010). Studies also found high concentrations of $\mathrm{Hg}$ in the air and soil of some cities (Fang et al. 2004; Feng et al. 2003; Zhang et al. 2004; Zhang and Wong 2007).

The aim of this work was to investigate the levels of $\mathrm{Hg}$ in topsoil of four provinces and one municipality of China. A total of 1,254 samples were collected and analyzed. The spatial distribution of $\mathrm{Hg}$ in these regions was then further discussed.

\section{Materials and methods}

\section{Sample collection}

The map of the study regions and the locations of sampling sites are shown in Fig. 1. Four provinces (Liaoning, Jiangsu,
Zhejiang and Sichuan) and one municipality (Chongqing) were selected for sample collection. These regions are located in northeast (Liaoning), east (Jiangsu and Zhejiang), and southwest (Sichuan and Chongqing) of China, representing different conditions of climate, soil property, and $\mathrm{Hg}$ emission and deposition. The basic information of the sampling regions is shown in Table 1.

A total of 1,254 samples were collected in 2010, which included 147 samples from Liaoning Province, 231 from Jiangsu Province, 311 from Zhejiang Province, 239 from Sichuan Province, and 326 from Chongqing Municipality. The sampling sites covered the whole regions except for Sichuan Province, where all the sampling sites were distributed in the central province. Therefore, the concentrations of $\mathrm{Hg}$ obtained for Sichuan Province may not be representative for the whole province, but can nevertheless provide a useful reference for further studies.

Topsoil samples $(0-20 \mathrm{~cm})$ were collected using clean stainless steel spades. The geographic location and land utilization for each sampling site were recorded. The samples were kept in polyethylene bags at $-20{ }^{\circ} \mathrm{C}$ after collection. In the laboratory, the soils were freeze-dried at $-45^{\circ} \mathrm{C}$, and ground to fine particles.

\section{Analysis}

The concentrations of total $\mathrm{Hg}$ in soil samples were determined with AFS-8120 cold vapor atomic fluorescence spectrometry (CVAFS, Beijing Titan Instruments Co., Ltd., China) after acid digestion. Approximately $0.05-0.1 \mathrm{~g}$ of soil was weighted and added into a $20 \mathrm{~mL}$ ampule, and $2 \mathrm{~mL}$ of $\mathrm{HNO}_{3}$ and $1 \mathrm{~mL}$ deionized water were added. After predigesting for $30 \mathrm{~min}$, the ampule was then sealed using a RFJ model manual ampule sealer (Jishou Zhongcheng Pharmacy Machine Co., Ltd., China). The ampule was heated for $2 \mathrm{~h}$ at $105{ }^{\circ} \mathrm{C}$ in an autoclave. After the solution was cooled down to room
Fig. 1 Map of study regions. Red circles indicate sampling sites

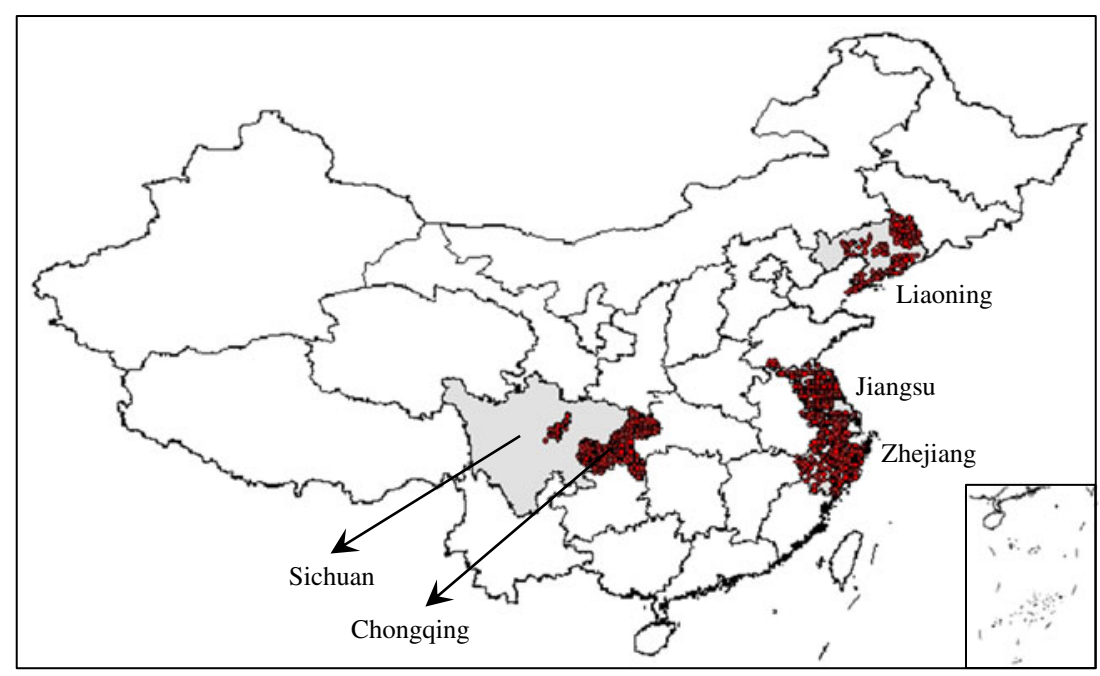


Table 1 Basic information of the sampling regions

${ }^{a}$ Data from Wu et al. (2006)

\begin{tabular}{llcccc}
\hline Sampling sites & Location & Area $\left(\times 10^{4} \mathrm{~km}^{2}\right)$ & $\begin{array}{l}\text { Population } \\
\text { (million) }\end{array}$ & $\begin{array}{l}\text { Total Hg emission } \\
\text { in 2003 (tonnes) }\end{array}$ & $\begin{array}{l}\text { Number of } \\
\text { samples }\end{array}$ \\
\hline Liaoning & $\begin{array}{r}118^{\circ} 53^{\prime}-125^{\circ} 46^{\prime} \mathrm{E} \\
38^{\circ} 43^{\prime}-43^{\circ} 26^{\prime} \mathrm{N}\end{array}$ & 14.59 & 43.75 & 45.9 & 147 \\
Jiangsu & $\begin{array}{r}116^{\circ} 18^{\prime}-121^{\circ} 57^{\prime} \mathrm{E} \\
30^{\circ} 45^{\prime}-35^{\circ} 20^{\prime} \mathrm{N}\end{array}$ & 10.26 & 78.66 & 23.6 & 231 \\
Zhejiang & $\begin{array}{r}118^{\circ} 01^{\prime}-123^{\circ} 08^{\prime} \mathrm{E} \\
27^{\circ} 01^{\prime}-31^{\circ} 10^{\prime} \mathrm{N}\end{array}$ & 10.18 & 54.43 & 21.0 & 311 \\
Sichuan & $\begin{array}{l}97^{\circ} 21^{\prime}-108^{\circ} 31^{\prime} \mathrm{E} \\
26^{\circ} 03^{\prime}-34^{\circ} 19^{\prime} \mathrm{N}\end{array}$ & 48.43 & 80.42 & 37.5 & 239 \\
Chongqing & $105^{\circ} 11^{\prime}-110^{\circ} 11^{\prime} \mathrm{E}$ & 8.24 & 31.44 & & 326 \\
& $28^{\circ} 10^{\prime}-32^{\circ} 13^{\prime} \mathrm{N}$ & & & & \\
\hline
\end{tabular}

temperature, the ampule was opened and $1 \mathrm{~mL}$ of digested solution was pipetted into a $15-\mathrm{mL}$ polyethylene terephthalate vial containing $9 \mathrm{~mL}$ of deionized water. The solution was mixed to homogeneity and then determined with CVAFS.

For the analytical quality control, reagent blanks, certified reference materials (CRMs), and sample replicates were also included in the analytical protocol. The determined concentrations of $\mathrm{Hg}$ in two sediment CRMs $\left(0.286 \pm 0.016 \mathrm{mg} \mathrm{kg}^{-1}\right.$ in GBW07310 and $0.060 \pm 0.005 \mathrm{mg} \mathrm{kg}^{-1}$ in GBW07312, $\mathrm{n}=5)$ were both in good agreement with their certified values $\left(0.280 \pm 0.040 \mathrm{mg} \mathrm{kg}^{-1}\right.$ in GBW07310 and $0.056 \pm$ $0.008 \mathrm{mg} \mathrm{kg}^{-1}$ in GBW07312), indicating the accuracy and reliability of the method.

The total organic carbon (TOC) contents were determined on a TOC analyzer (O.I Analyzer, College Station, TX, USA). About $0.1 \mathrm{~g}$ of soil was weighed and loaded into a quartz combustion cup. Prior to combustion, the sample was wet with $5 \%$ phosphoric acid and heated at $250{ }^{\circ} \mathrm{C}$ for 1 min to purge the inorganic carbon.

For $\mathrm{pH}$ analysis, $4 \mathrm{~g}$ of soil was weighed into a $25 \mathrm{~mL}$ beaker and $10 \mathrm{~mL} \mathrm{KCl}$ solution $\left(1 \mathrm{~mol} \mathrm{~L}^{-1}\right)$ was added. The suspension was steered at regular intervals for $30 \mathrm{~min}$. The $\mathrm{pH}$ was recorded with a $\mathrm{pH}$ meter (ORION 3 STAR, Thermo Scientific).

\section{Geochemical mapping}

In order to study the spatial distribution of $\mathrm{Hg}$, the software ArcGIS 10 was used to produce the contour maps by applying the Kriging method for the geospatial interpolation of the $\mathrm{Hg}$ data.

\section{Results and discussion}

The concentrations of $\mathrm{Hg}$

The concentrations of $\mathrm{Hg}$ in soil samples are shown as boxplots in Fig. 2. The concentrations of $\mathrm{Hg}$ were in the range
0.001-1.075 $\mathrm{mg} \mathrm{kg}^{-1}$ (average, $0.064 \mathrm{mg} \mathrm{kg}^{-1}$ ) for Liaoning Province, $0.006-2.758 \mathrm{mg} \mathrm{kg}^{-1}$ (average, $0.100 \mathrm{mg} \mathrm{kg}^{-1}$ ) for Jiangsu Province, 0.002-1.946 $\mathrm{mg} \mathrm{kg}^{-1}$ (average, $0.110 \mathrm{mg} \mathrm{kg}^{-1}$ ) for Zhejiang Province, $0.003-$ $0.708 \mathrm{mg} \mathrm{kg}^{-1}$ (average, $0.154 \mathrm{mg} \mathrm{kg}^{-1}$ ) for Sichuan Province, and $0.001-3.102 \mathrm{mg} \mathrm{kg}^{-1}$ (average, $0.098 \mathrm{mg} \mathrm{kg}^{-1}$ ) for Chongqing Municipality.

The average concentration of $\mathrm{Hg}$ in soils from Liaoning Province was similar to the national average of $0.065 \mathrm{mg} \mathrm{kg}^{-1}$ of $\mathrm{Hg}$ in soil (Wei et al. 1991), while the other provinces exhibited higher average levels. Comparisons with published data on $\mathrm{Hg}$ in the study regions are shown in Table 2. The studies in tea garden soil from Sichuan Province and vegetable field soil from Chongqing Municipality were significantly different from this work, possibly because of the specific sampling areas in those studies. In addition, differences were also found among the ranges of $\mathrm{Hg}$ concentrations. However, as a whole, the average values for each region were similar with previously published data, indicating no significant changes of $\mathrm{Hg}$ concentrations in topsoil of the study regions.

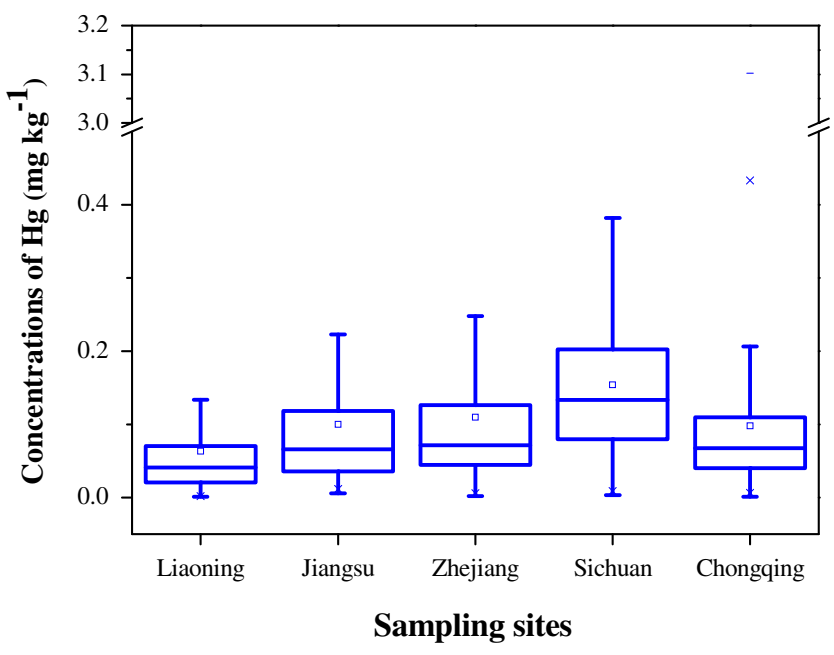

Fig. 2 Box-plot of $\mathrm{Hg}$ concentrations in soil samples 
Table 2 Comparison of published concentrations of $\mathrm{Hg}$ in study regions ( $\mathrm{mg} \mathrm{kg}^{-1}$ )

\begin{tabular}{|c|c|c|c|c|c|c|c|}
\hline Type of samples & $\begin{array}{l}\text { Number } \\
\text { of samples }\end{array}$ & Liaoning & Jiangsu & Zhejiang & Sichuan & Chongqing & Reference \\
\hline Agricultural soil & 2256 & $\begin{array}{l}0.076 \\
(0.014-0.438)^{\mathrm{a}}\end{array}$ & & & & & Hou et al. 2011 \\
\hline Agricultural soil & 908 & & & $\begin{array}{l}0.130 \\
(0.020-1.240)\end{array}$ & & & Cheng et al. 2007 \\
\hline Topsoil & 24186 & & $\begin{array}{l}0.082 \\
(0.005-8.090)\end{array}$ & & & & Liao et al. 2009 \\
\hline Tea garden soil & 510 & & & & $\begin{array}{l}0.039 \\
\quad \text { (n.d. }-0.368)\end{array}$ & & Tan et al. 2005 \\
\hline Agricultural soil & 455 & & & & & $\begin{array}{l}0.092 \\
(0.017-0.546)^{\mathrm{b}}\end{array}$ & Yang et al. 2006 \\
\hline Vegetable field soil & 144 & & & & & $\begin{array}{l}0.196 \\
(0.028-0.669)\end{array}$ & Huang et al. 2003 \\
\hline Topsoil & 1254 & $\begin{array}{l}0.064 \\
(0.001-1.075)\end{array}$ & $\begin{array}{l}0.100 \\
(0.006-2.758)\end{array}$ & $\begin{array}{l}0.110 \\
(0.002-1.946)\end{array}$ & $\begin{array}{l}0.154 \\
\quad(0.003-0.708)\end{array}$ & $\begin{array}{l}0.098 \\
(0.001-3.102)\end{array}$ & This work \\
\hline
\end{tabular}

${ }^{\text {a }}$ Collected from Shenyang City area

${ }^{\mathrm{b}}$ Collected from Three Gorges Reservoir area

Spatial distribution

The concentrations of $\mathrm{Hg}$ were used as input data for contour mapping with the software ArcGIS 10. The spatial distributions of $\mathrm{Hg}$ concentrations in topsoil of Liaoning
Province, Jiangsu Province, Zhejiang Province, and Chongqing Municipality are shown in Fig. 3. The contour map for Sichuan Province was not drawn because the sampling sites did not cover the whole region. As shown in Fig. 3, the concentrations of $\mathrm{Hg}$ in topsoil varied largely
Fig. 3 The spatial distribution of $\mathrm{Hg}$ in topsoil (in milligrams per kilogram). a Liaoning, b Jiangsu, c Zhejiang, and d Chongqing

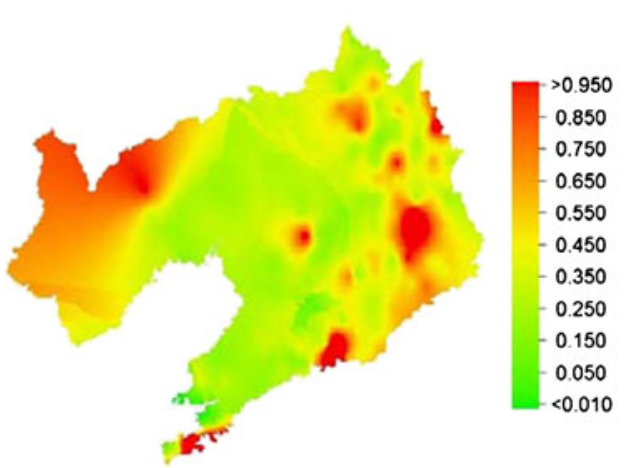

(a)

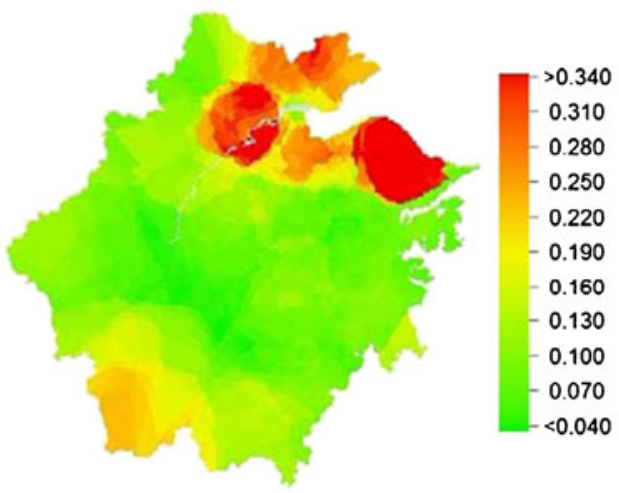

(c)

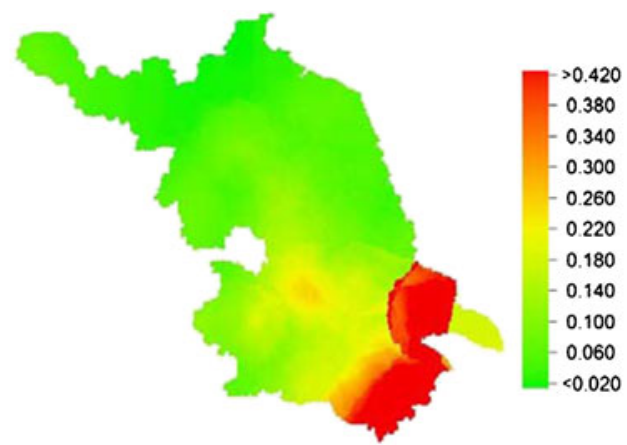

(b)

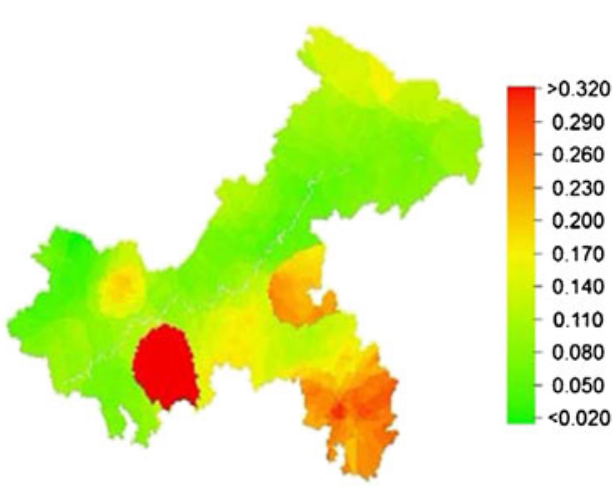

(d) 
Table 3 Correlations of $\mathrm{Hg}$ concentrations, TOC contents, and $\mathrm{pH}$ values

${ }^{*} p=0.99$, significantly correlated

\begin{tabular}{lllll}
\hline Sampling sites & TOC $(\%)$ & $\mathrm{pH}$ & $R_{\mathrm{Hg}, \mathrm{TOC}}$ & $R_{\mathrm{Hg}, \mathrm{pH}}$ \\
\hline Liaoning $(n=50)$ & $2.66(0.07-6.96)$ & $6.0(4.0-8.0)$ & $0.504^{*}$ & -0.153 \\
Jiangsu $(n=50)$ & $1.91(0.66-3.41)$ & $6.5(4.0-7.0)$ & 0.307 & $-0.537^{*}$ \\
Zhejiang $(n=50)$ & $1.74(0.19-5.97)$ & $6.2(5.4-7.0)$ & $0.446^{*}$ & -0.092 \\
Sichuan $(n=50)$ & $2.30(0.13-3.99)$ & $6.2(3.4-7.0)$ & $0.394^{*}$ & -0.204 \\
Chongqing $(n=50)$ & $1.59(0.29-6.08)$ & $6.0(3.1-7.0)$ & $0.379^{*}$ & 0.014 \\
Total $(n=250)$ & $2.04(0.07-6.96)$ & $6.2(3.1-8.0)$ & $0.317^{*}$ & -0.085 \\
\hline
\end{tabular}

upon the sampling locations, and some high-Hg hotspots were found. The concentrations of $\mathrm{Hg}$ could be affected by numerous factors such as soil property, natural abundance of $\mathrm{Hg}$, the input and output of $\mathrm{Hg}$ in soil, human activities, and more. Therefore, further study is necessary to identify the sources of those significantly high-Hg areas.

The estimated amounts of $\mathrm{Hg}$ emitted from study regions in 2003 have been shown in Table 1. Liaoning emitted the largest amount of $\mathrm{Hg}$ but the average concentration of $\mathrm{Hg}$ in topsoil was the lowest. The $\mathrm{Hg}$ emitted from Sichuan was less than Liaoning, but it had the highest $\mathrm{Hg}$ level in topsoil. The amounts of $\mathrm{Hg}$ emitted from Jiangsu and Zhejiang were low, and the levels of $\mathrm{Hg}$ in topsoil were in the middle. Therefore, as a whole, the average concentrations of $\mathrm{Hg}$ in topsoil of study regions were not correlated with $\mathrm{Hg}$ emission. But it should be noticed that the contents of $\mathrm{Hg}$ in soil could be affected by $\mathrm{Hg}$ emissions in some specific sites, especially in sites near coal-burning plants and $\mathrm{Hg}$ mining areas.

In order to investigate the correlations of $\mathrm{Hg}$ concentrations, TOC contents and $\mathrm{pH}$ in soils, 50 samples were chosen for each region and the TOC and $\mathrm{pH}$ were analyzed. The samples were selected mainly based on their geographic locations and even-distributed in study regions. The average and ranges of TOC and $\mathrm{pH}$ of selected soils are shown in Table 3. The TOC contents ranged from 0.07 to $6.96 \%$ with an average of $2.04 \%$. The $\mathrm{pH}$ values were between 3.1 and 8.0 with an average of 6.2. In Jiangsu, the concentrations of $\mathrm{Hg}$ were not correlated with TOC but significantly correlated with $\mathrm{pH}$. However, the concentrations of $\mathrm{Hg}$ were significantly correlated with TOC contents but not correlated with $\mathrm{pH}$ in other four regions. The same correlations were also found when taking all the samples together. This indicated that the influence of TOC on $\mathrm{Hg}$ concentrations is more significant than that of $\mathrm{pH}$ in collected samples.
According to China Environmental Quality Standard for Soils GB15618-1995 (NSPRC 1995), soils can be divided into three grades on the basis of $\mathrm{pH}$, metals $(\mathrm{Cd}, \mathrm{Hg}, \mathrm{As}, \mathrm{Cu}$, $\mathrm{Pb}, \mathrm{Cr}, \mathrm{Zn}$ and $\mathrm{Ni}$ ), and organic pollutants ( $\mathrm{HCHs}$ and DDTs). Soils of Grade I are considered uncontaminated and are suitable for natural reserves, pasture lands and other protected soils. Grade II is suitable for agriculture soils, and Grade III is for mining areas or industrial soils. The limitations of $\mathrm{Hg}$ concentration for each grade are described in Table 4. The percentages of $\mathrm{Hg}$ concentrations in collected soils for each grade were calculated. About $99 \%$ of all soil samples were classified as Grade I and Grade II. More than $80 \%$ of soils from Liaoning Province, Jiangsu Province, Zhejiang Province, and Chongqing Municipality, ranked Grade I, which can be considered as uncontaminated by $\mathrm{Hg}$. Although only $54.0 \%$ of soils collected from Sichuan Province ranked Grade I, all the others were in the range of Grade II, indicating they were still safe for agricultural use. However, the concentrations of $\mathrm{Hg}$ in $0.3-0.4 \%$ of soils collected from Jiangsu Province, Zhejiang Province and Chongqing Municipality exceeded the limitation for Grade III, indicating contamination of $\mathrm{Hg}$ in these sites. The sources and potential risks of $\mathrm{Hg}$ in these sites should be considered and further studied in detail.

\section{Conclusions}

Although differences were found among the ranges of $\mathrm{Hg}$ concentrations, the average values for each region were similar with previously published data. The concentrations of $\mathrm{Hg}$ in topsoil varied largely upon the sampling locations, which could be attributed to environmental and geographical factors. The concentrations of $\mathrm{Hg}$ in $0.3-0.4 \%$ of soils collected from
Table 4 Distribution of collected soil samples among different grades based on Hg concentrations (GB 15618-1995, NSPRC 1995)

\begin{tabular}{llccccc}
\hline Grade & $\begin{array}{l}\text { Ranges } \\
\left(\mathrm{mg} \mathrm{kg}^{-1}\right)\end{array}$ & Liaoning (\%) & Jiangsu (\%) & Zhejiang (\%) & Sichuan (\%) & Chongqing (\%) \\
\hline I & $\leq 0.150$ & 93.9 & 86.6 & 82.6 & 54.0 & 86.5 \\
II & $0.150-1.000$ & 5.4 & 13.0 & 16.7 & 46.0 & 12.9 \\
III & $1.000-1.500$ & 0.7 & 0.0 & 0.3 & 0.0 & 0.3 \\
$>$ III & $>1.500$ & 0.0 & 0.4 & 0.3 & 0.0 & 0.3 \\
\hline
\end{tabular}


Jiangsu Province, Zhejiang Province, and Chongqing Municipality exceeded the limitation for Grade III, indicating contamination of $\mathrm{Hg}$ in these sites. Further studies on the potential sources and environmental risks of $\mathrm{Hg}$ in these sites are warranted.

Acknowledgments The work described here was supported by the National Basic Research Program of China (2009CB421605) and the National Natural Science Foundation of China (20977107, 20890111, 20937002, and 21120102040).

\section{References}

Cheng JL, Shi Z, Zhu YW (2007) Assessment and mapping of environmental quality in agricultural soils of Zhejiang Province, China. J Environ Sci 19:50-54

Fang F, Wang Q, Li J (2004) Urban environmental mercury in Changchun, a metropolitan city in Northeastern China: source, cycle, and fate. Sci Total Environ 330:159-170

Feng X (2005) Mercury pollution in China-an overview. In: Pirrone N, Mahaffey KR (eds) Dynamics of mercury pollution on regional and global scales: atmospheric processes and human exposures around the world. Springer, US, pp 657-678

Feng X, Tang S, Shang L, Yan H, Sommar J, Lindqvist O (2003) Total gaseous mercury in the atmosphere of Guiyang, PR China. Sci Total Environ 304:61-72

Hou L, Zhang DF, Zhang YL (2011) The spatial distribution features and the status evaluation of heavy metal in farmland soils in Shenyang area. J Liaoning Forestry Sci Technol 3:5-8 (in Chinese)

Huang Y, Li QL, Liu GD, Zeng XY (2003) The coherency analysis of heavy metals in soils and vegetables of the vegetable bases of Chongqing. Environ Monit China 19:42-47 (in Chinese)

Jian XD, Shen YW, Yao W, Wang YJ, Zhang X (2009) Status analysis and reduction countermeasures of China's mercury supply and demand. Res Environ Sci 22:788-792

Jiang GB, Shi JB, Feng XB (2006) Mercury pollution in China. Environ Sci Technol 40:3672-3678

Liao QL, Hua M, Jin Y, Huang SS, Zhu BW, Weng ZH, Pan YM (2009) A preliminary study of the distribution and pollution source of heavy metals in soils of Jiangsu Province. Geol China 36:1163-1174 (in Chinese)

Meng B, Feng XB, Qiu GL, Cai Y, Wang DY, Li P, Shang LH, Sommar J (2010) Distribution patterns of inorganic mercury and methylmercury in tissues of rice (Oryza sativa L.) plants and possible bioaccumulation pathways. J Agric Food Chem 58:4951-4958
Meng B, Feng X, Qiu G, Liang P, Li P, Chen C, Shang L (2011) The process of methylmercury accumulation in rice (Oryza sativa L.). Environ Sci Technol 45:2711-2717

NSPRC (National Standards of the People's Republic of China) (1995) Standards for soil environmental quality (GB 15618-1995). (in Chinese)

Pacyna EG, Pacyna JM, Steenhuisen F, Wilson S (2006) Global anthropogenic mercury emission inventory for 2000. Atmos Environ 40:4048-4063

Pirrone N, Cinnirella S, Feng X, Finkelman RB, Friedli HR, Leaner J, Mason R, Mukherjee AB, Stracher GB, Streets DG, Telmer K (2010) Global mercury emissions to the atmosphere from anthropogenic and natural sources. Atmos Chem Phys 10:5951-5964

Qiu GL, Feng XB, Li P, Wang SF, Li GH, Shang LH, Fu XW (2008) Methylmercury accumulation in rice (Oryza sativa L.) grown at abandoned mercury mines in Guizhou, China. J Agric Food Chem 56:2465-2468

Shi JB, Ip CC, Tang CW, Zhang G, Wu RS, Li XD (2007) Spatial and temporal variations of mercury in sediments from Victoria Harbour, Hong Kong. Mar Pollut Bull 54:480-485

Shi JB, Ip CC, Zhang G, Jiang GB, Li XD (2010) Mercury profiles in sediments of the Pearl River Estuary and the surrounding coastal area of South China. Environ Pollut 158:1974-1979

Streets DG, Devane MK, Lu Z, Bond TC, Sunderland EM, Jacob DJ (2011) All-time releases of mercury to the atmosphere from human activities. Environ Sci Technol 45:10485-10491

Tan HP, Chen NW, Huang P, Ye SR (2005) Background and evaluation of heavy metal elements in the tea garden soil in Sichuan. Southwest China J Agric Sci 18:747-751 (in Chinese)

Tipping E, Poskitt JM, Lawlor AJ, Wadsworth RA, Norris DA, Hall JR (2011) Mercury in United Kingdom topsoils; concentrations, pools, and critical limit exceedances. Environ Pollut 159:3721-3729

UNEP (United Nations Environment Programme) (2010) Toolkit for identification and quantification of mercury release

Wei FS, Chen JS, Wu YY, Zheng CJ (1991) Study on soil background values of China. Environ Sci 4:12-19 (in Chinese)

Wu Y, Wang SX, Streets DG, Hao JM, Chan M, Jiang JK (2006) Trends in anthropogenic mercury emissions in China from 1995 to 2003. Environ Sci Technol 40:5312-5318

Yang M, Liu HB, Wu W (2006) Spatial variability of heavy metals in soil of Three Gorges Reservior in Chongqing. Chinese J EcoAgric 14:100-103 (in Chinese)

Zhang H, Feng XB, Larssen T, Qiu GL, Vogt RD (2010) In inland China, rice, rather than fish, is the major pathway for methylmercury exposure. Environ Health Perspect 118:1183-1188

Zhang L, Wong MH (2007) Environmental mercury contamination in China: sources and impacts. Environ Int 33:108-121

Zhang L, Wang QC, Li ZB, Shao ZG (2004) Mercury contamination in cities of China and countermeasures. Ecol Environ 13:410-413 (in Chinese) 